Ann. Biol. anim. Bioch. Biophys., 1977, 17 (1), 1-7.

\title{
Absence of seasonal variation in the length of the menstrual cycle and the fertility of the crab-eating macaque (Macaca fascicularis) raised under natural daylight ratio
}

par D. C. DANG

Laboratoire d'Anatomie, U. E. R. Biomédicale

45, rue des Saints-Fères, 75006 Paris

Laborafoire de Physiologie de Ia Reproduction, Université Paris-VI

I. N. R. A., 78350 jouy-en-josas, France

Summary. Fifty-five Macaca fascicularis females are raised in the laboratory at relatively constant humidity and temperature but under natural daylight ratio in Paris. Their 275 menstrual cycles studied over 3 years show no variation in mean length during the year (fig. 2). Dividing the year into four different daylight ratio lengths (short, 8-9 hours ; increasing from 9 to 15 hours ; long, 15-16 hours; decreasing from 16 to 8 hours), we find no difference in the conception rate which is 35 p. 100 (table 4). Contrary to lemurs, the daylight ratio seems to play no role in the reproduction of macaque females. The length of the menstrual cycle of Macaca fascicularis is $34.5 \pm 1.3$ days ; the median is 32 days and the mode 29 days (fig. 1 ).

\section{Introduction.}

The photoperiod plays an important role in the control of the seasonal reproduction cycle of many mammals. A seasonal reproduction cycle has been described in several species of non-human primates at liberty (Lancaster and Lee, 1965) and in Macaca fascicularis raised at semi-liberty (Gauquelin, 1965). The seasonal factors controlling reproduction, however, have not been studied much by experimentation.

In this report we test the effect of the photoperiod on the length of the menstrual cycle and fertility of the crab-eating monkey Macaca fascicularis.

\section{Material and methods.}

Fifty-five adult females weighing $3.5-4.5 \mathrm{~kg}$ were studied over a 3-years period. They were imported from southeast Asia, arriving at six different times : February, 
March, October, December 1973 and January and November 1975. The fertility of 48 of the animals was detected by birth or cesarian after analysis of the results at the end of the study. Forty-nine females were given 1 to 3 progesterone treatments to synchronize menstrual cycles (Dang, 1974). Twenty-nine of the 48 animals had 1 to 3 cesarians during the first half of pregnancy.

The monkey room situated on the terrace of the 8th floor has a roof of large sheets of tinted glass interspaced with transparent sheets, thus allowing animals a choice between shadow and sunlight. Except for the month of August, it is kept at a temperature of about $25^{\circ} \mathrm{C}$ all year long. This is obtained by a current of filtered air blowing over water containers. The hygrometry varies only during the weekly cleaning of the room. Macaques are thus raised under natural daylight ratio varying between 8 and 16 hours of light per day without additional artificial lighting.

The feed used throughout the experiment mainly consists of granules with additional small amounts of fruits and vegetables from time to time.

Two to three females are raised together in a cage $(h=130 \mathrm{~cm}, 70 \mathrm{~cm}, 90 \mathrm{~cm})$ depending on their mutual agreement. The six adult males are housed in individual cages, each placed in the monkey room so that there is permanent male-female visual contact between all the animals.

Females are put in turn with one of the males for 24 or 48 hours from day 12-13 to day 14-15 of the menstrual cycle. The first day of menstruation represents day 0 of the cycle. Conception is recognized either by the appearance of characteristic postimplantatory menstruation (Dang, 1974) or by palpation of the uterus through the rectum from day 28 postcoitum. Birth or cesarian confirms the diagnosis.

The conception rate is the ratio between the total number of spontaneous cycles during which there is conception and the total number of spontaneous cycles during which mating is possible. A vaginal smear, taken every day with a cotton swab from day 20 of the menstrual cycle, is used to detect menstruation. This technique is conti-

TABLE 1 Menstrual cycle length of progesterone-treated
females during the year

\begin{tabular}{|c|c|}
\hline Animal & $\bar{x} \pm t . S E$ \\
\hline 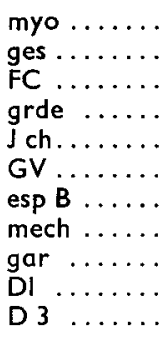 & $\begin{array}{l}31.7 \pm 6.6 \\
33.0 \pm 2.6 \\
30.2 \pm 1.6 \\
38.0 \pm 19.7 \\
35.3 \pm 2.6 \\
33.7 \pm 6.3 \\
27.8 \pm 4.5 \\
34.6 \pm 11.2 \\
31.8 \pm 7.3 \\
43.2 \pm 7.0 \\
35.0 \pm 3.7\end{array}$ \\
\hline
\end{tabular}

TABLE 2

Menstrual cycle length of normal females during the year

\begin{tabular}{ll}
\hline \multicolumn{1}{c}{ Animal } & $\bar{x} \pm \mathrm{t}$ SE \\
\hline & \\
& \\
pt $\ldots \ldots \ldots$ & $32.2 \pm 5.5$ \\
im $\ldots \ldots$ & $34-28$ \\
Alec $\ldots \ldots$ & $26-25$ \\
Luci $\ldots \ldots$ & $28.6 \pm 1.6$ \\
Thal $\ldots \ldots$ & $37.0 \pm 12.8$ \\
Jun $\ldots \ldots$ & $28.3 \pm 1.0$ \\
\end{tabular}


nued until no menstruation is detected for 4 consecutive days. The menstrual cycles in this report are thus those during which no pregnancy was established. A cycle is assigned to the month of the year during which most of the cycle occurred.

\section{Results.}

Tables 1 and 2 and the analysis of variance show that the length of the menstrual cycle after progesterone treatment is stopped, is not different than that of spontaneous cycles in the same females or in untreated animals. All the cycles are thus regrouped to obtain maximum usable data.

The histogram of figure 1 shows the length of the menstrual cycle with a mean at $34.5 \pm 1.3$ days; the median is at 32 days and the mode at 29 days. No cycle lasted less than 22 days while 15 p. 100 continued for more than 40 days.

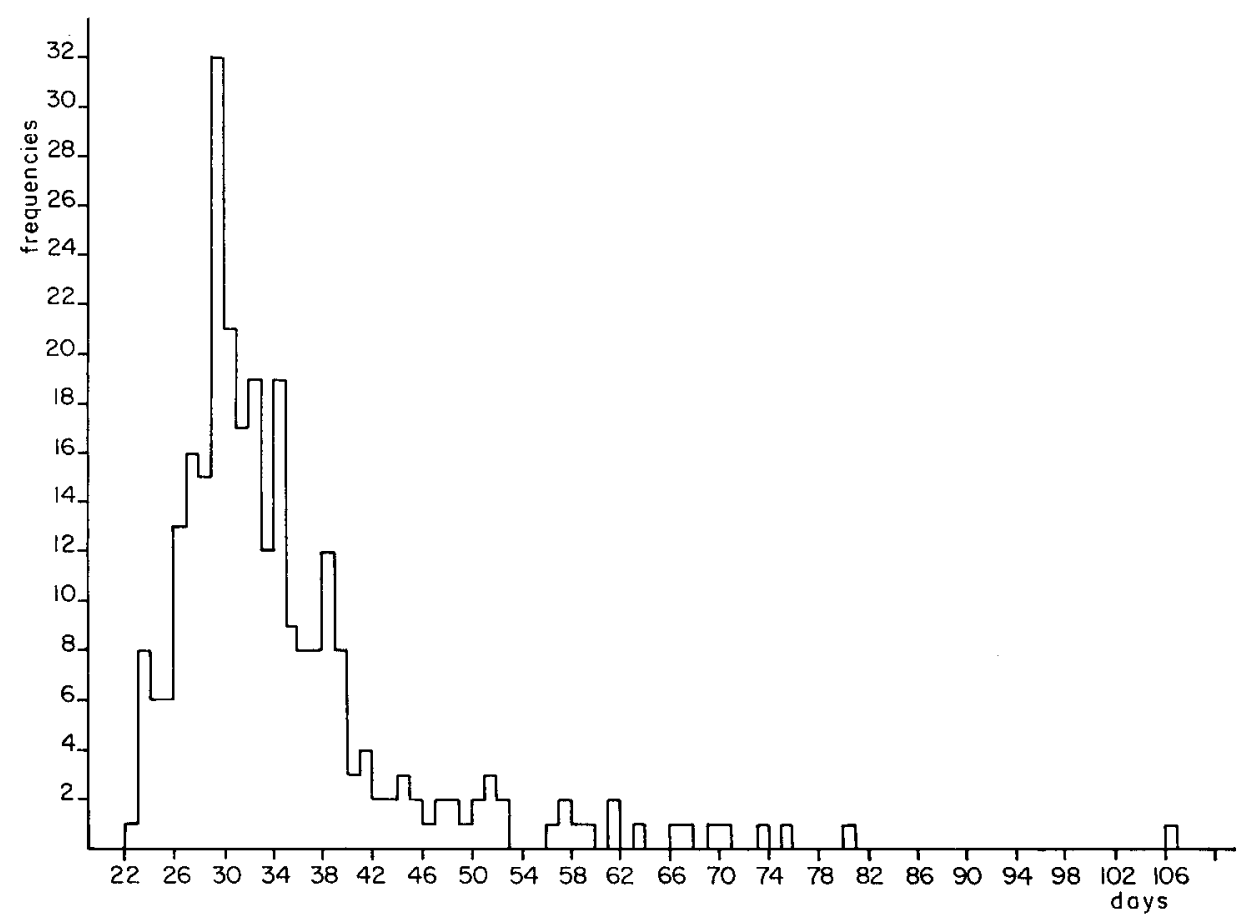

FIG. 1. - Histogram of menstrual cycle lengths

Figure 2 shows the relation between daylight ratio and mean length of all menstrual cycles for every month of the year. This mean is stable during the year and is not affected by the photoperiod. Dividing up the year into different daylight ratios (short 
daylight ratio of 8-9 hours, December and January; daylight ratio increasing from 9 to 15 hours in February, March, April, May; long daylight ratio of 15-16 hours in June and July ; daylight ratio decreasing from 16 to 8 hours from August to November), we found no change in the length of cycles. The percentages of cycles longer or less than 32 days (representing the menstrual cycle median in this species) do not differ significantly (table 3).

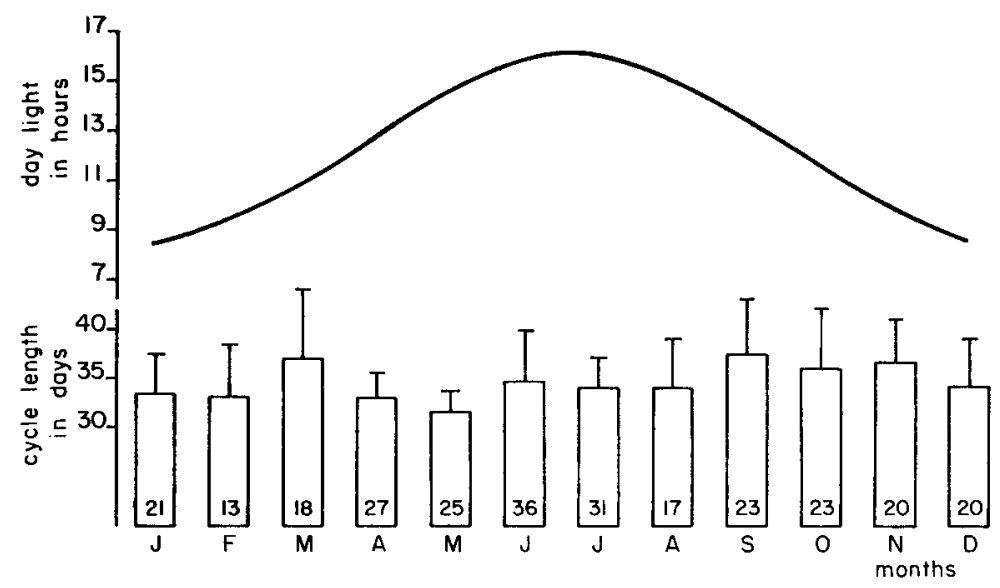

FIG. 2. - Mean duration of menstrual cycle each month. 21 : number of cycles observed

Conception rate did not vary statistically either during the four daylight ratios studied (table 4). Thus, for the Macaca fascicularis females in our laboratory, presented to the male for 24-48 hours from day 12-13 to day 14-15 of the menstrual cycle, we obtained an overall conception rate of 35 p. 100 or $69 / 196$.

TABLE 3

Daylight ratio and percentage of menstrual cycles longer or shorter than 32 days

\begin{tabular}{ccccc}
\hline Daylight ratios & $\begin{array}{c}\text { Short } \\
8-9 \text { hrs. }\end{array}$ & $\begin{array}{c}\text { Increasing } \\
\text { from } 9 \text { to } 15 \text { hrs. }\end{array}$ & $\begin{array}{c}\text { Long } \\
15-16 \text { hrs. }\end{array}$ & $\begin{array}{c}\text { Decreasing } \\
\text { from } 16 \text { to } 8 \text { hrs. }\end{array}$ \\
\hline Month & Dec. to Jan. & Feb. to May & June to July & Aug. to Nor. \\
\hline$>32$ days & $\begin{array}{c}44 \text { p. } 100 \\
18 / 41\end{array}$ & $\begin{array}{c}41 \text { p. } 100 \\
34 / 83\end{array}$ & $\begin{array}{c}43 \text { p. } 100 \\
30 / 68\end{array}$ & $\begin{array}{c}46 \text { p. } 100 \\
38 / 82\end{array}$ \\
\hline$<32$ days & $\begin{array}{c}49 \text { p. } 100 \\
20 / 41\end{array}$ & $\begin{array}{c}49 \text { p. } 100 \\
41 / 83\end{array}$ & $\begin{array}{c}51 \text { p. } 100 \\
35 / 68\end{array}$ & $\begin{array}{c}46 \text { p. } 100 \\
38 / 82\end{array}$ \\
\hline
\end{tabular}


TABLE 4

Conception rate in relation to daylight ratios (spontaneous menstrual cycles)

\begin{tabular}{ccccc}
\hline Daylight ratios & Short & Increasing & Long & Decreasing \\
\hline $\begin{array}{c}\text { Conception } \\
\text { rate }\end{array}$ & $\begin{array}{c}32 \text { p. } 100 \\
8 / 25\end{array}$ & $\begin{array}{c}32 \text { p. } 100 \\
20 / 62\end{array}$ & $\begin{array}{c}36 \text { p. } 100 \\
17 / 47\end{array}$ & $\begin{array}{c}39 \text { p. } 100 \\
24 / 62\end{array}$ \\
\hline
\end{tabular}

\section{Discussion.}

The annual reproduction cycle of the macaque living at liberty (Lancaster and Lee, 1965) or semi-liberty (Gauquelin, 1965) still persists when the animals are raised in the laboratory under constant daylight ratio, temperature and humidity (Josimovich and Knobil, 1961 ; Keverne and Michael, 1970 ; Riesen et al., 1971). However, this cycle disappears little by little in a more or less long time ( 2 to 5 years) depending on the species. Its disappearance is quicker in Macaca fascicularis than in Macaca mulatta (Valerio, 1969). There is thus slow adaptation to a new stable environment.

Analysis of the data obtained for 3 years in our laboratory on the length of the menstrual cycle and the fertility of Macaca fascicularis raised at a relatively constant temperature, humidity and regimen, but under seasonal variation of natural daylight ratio in Paris, shows no adaptation or effect of the daylight ratio whether it be short, long, increasing or decreasing. This result confirms those of Erickson (1964) and Birkner (1970) on Macaca mulatta and of Dukelow (1974) on Macaca fascicularis, Macaca nemestrina and Macaca arctoides. These macaques thus differ from lemurs in which sexual activity is strictly controlled by the daylight ratio (Petter-Rousseaux, 1970, 1972, 1975 ; Van Horn, 1975).

The conception rate of 35 p. 100 per cycle of our colony is relatively low although the number of infertile females is only $13 \mathrm{p}$. 100. Short cohabitation with the males for 24-48 hours from day 12-13 to day 14-15 of the menstrual cycle may be the cause. In the same species Valerio et al. (1969) obtained about 70 p. 100 conception by putting the females with the males either at day 11,12, 13 or 14 of the cycle, while MacDonald (1971) reports 14 sur 15 females were pregnant when he put them with the males from day 11 to 15 . Fujiwara et al. (1969) noted that only 56 p. 100 of the females were pregnant when they were mated for one week from day 11 to 18 . Most of our females also had cesarians to recover the fetus and these same intact females before cesarian and after treatment with adequate daily doses of progesterone had a higher conception rate of $8 / 11$ (Dang, 1974).

The length of the Macaca fascicularis menstrual cycle is no different than found by other authors (Spiegel, 1950 ; Fujiwara et al., 1967 ; Kerber and Reese, 1969 ; Jeweft and Dukelow, 1972). Cycles longer than 40 days were observed all year long in our colony. This transitory amenorrhea could be due to either embryonic mortality because females were mated or to psychic stress which may occur when infra-human primates are raised in the laboratory. 
Acknowledgements. - We wish to thank the Caisse Nationale de l'Assurance des Travailleurs Salariés and the Centre National de la Recherche Scientifique which graciously contributed funds for the achievement of this work. We also thank Mr. G. Apheceix for his efficient technical assistance.

Résumé. L'étude pendant trois ans de 275 cycles menstruels de 55 femelles de Macaca fascicularis élevées au laboratoire à humidité et température relativement constantes mais sous photopériode naturelle à Paris n'a révélé aucune variation de la durée moyenne du cycle au cours de l'année (fig. 2).

En divisant l'année en quatre intervalles suivant la durée de la photopériode : courte 8-9 h, croissante de 9 à $15 \mathrm{~h}$, longue $15-16 \mathrm{~h}$, et décroissante de 16 à $18 \mathrm{~h}$, nous n'avons trouvé aucune différence dans le taux de conception qui est de 35 p. 100 (tabl. 4).

Contrairement aux Lémuriens, la durée d'éclairement ne semble donc jouer aucun rôle sur la reproduction des femelles macaques.

La durée du cycle menstruel de Macaca fascicularis est de $34,5 \pm 1,3$ jours, la médiane est à 32 jours et le mode à 29 jours (fig. 1).

\section{References}

BIRKNER F. E., 1970. Photic influences on primate (Macaca mulatta) reproduction. Lab. Anim. Care, 20, 181-185.

DANG D. C., 1974. Maîtrise du cycle menstruel par la progestérone et fertilité chez Macaca fascicularis. J. Gynécol. Obstśt. Biol. Reprod., 3, 469-476.

DUKELOW W. R., 1974. Captive breeding of nonhuman primates. Proc. Am. Ass. Zool., Vet., 54-67.

ECKSTEIN P., KELLEYW. A., 1966. A Survey of the breeding performance of Rhesus monkeys in the laboratory. Symp. Zool. Soc. Lond., 17, 91.

ERIKSON L. B., 1964. Light-dark periodicity and the rhesus monkey menstrual cycle. Fertil. Steril., 15, 352-366.

FUJIWARA T., HONJO S., IMAIZUMI K., 1969. Practice of breeding of cynomolgus monkeys (Macaca irus) under Jaboratory conditions (in Japanese). Exp. Anim., 18, 29-40.

FUJIWARA T., UCHINO I., HONJO S., IMAIZUMI K., IMANICHI T., 1967. Normal range of the menstrual cycle of cynomolgus monkeys under iaboratory conditions. Jap. J. Med. Sci. Biol., 20, 505-507.

GAUQUELIN M. F., 1968. Le cycle annuel de reproduction du macaque, Macaca irus. Bull. Biol., 2, 261-270.

JEWETT D. A., DUKELOW W. R., 1972. Cyclicity and gestation of Macaca fascicularis. Primates, 13, 32.7-330.

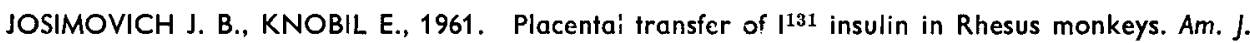
Physiol., 200 471-476.

KERBER W. T., REESE W. H., 1969. Comparison of the menstrual cycle of Cynomolgus and Rhesus monkeys. Fertil. Steril., 20, 975-979.

KEVERNE E. B., MICHAEL R. P., 1970. Annual changes in the menstruation of Rhesus monkeys. J. Endocrinol., 48, 669-670.

LANCASTER J. B., LEE R. B., 1965. The annual reproductive cycle in monkeys and apes, 486-515. in DEVORE I., Primate Behaviour, Holt, Rinehart and Winston, New York.

MACDONALD G. J., 1971. Reproductive patterns of three species of macaques. Fertil. Steril., 22, 373-377. 
PETTER-ROUSSEAUX A., 1970. Observations sur l'influence de la photopériode sur l'activité sexuelle chez Microcebus murinus (Miller 1777) en captivité. Ann. Biol. anim. Bioch. Biophys., 10, 203-208.

PETTER-ROUSSEAUX A., 1972. Application d'un système semestriel de variation de la photopériode chez Microcebus murinus (Miller 1777) en captivité. Ann. Biol. anim. Bioch. Biophys., 12, 367-375.

PETTER-ROUSSEAUX A., 1975. Activité sexuelle de Microcebus murinus (Miller, 1777) soumis à des régimes photopériodiques expérimentaux. Ann. Biol. anim. Bioch. Biophys., 15, 503-508.

RIESEN J.W., MEYER R. K.,WOLF R. C., 1971. The effect of season on occurence of ovulation in the Rhesus monkey. Biol. Reprod., 5, 111-114.

SPIEGEL A., 1950. Weitere Beobachtungen und Untersuchungen über die Fortpflanzung bei Javamaken. Arch. Gynäk., 177, 590-629.

VALIERO D. A., PALLOTTA A. J., COURTNEY K. D., 1969. Experiences in large scale breeding of simians for medical experimentation. Ann. N. Y. Acad. Sci., 162, 282-296.

VAN HORN R. N., 1975. Primate breeding season : photoperiodic regulation in captive Lemur catta. Folia Primatol., 24, 203-220. 